\title{
Inhibition of glucose-induced insulin secretion by a peripheral-type benzodiazepine receptor ligand (PK 11195)
}

Didier Pujalte, Sylvie ${ }^{\#}$ Claeysen, Samuel Dietz, Jeannie Chapal, Dominique Hillaire-Buys, Pierre Petit ${ }^{*}$

Laboratory of Pharmacology (Research Unit UPRES EA 1677),

Faculty of Medicine, Institute of Biology,

Montpellier I University, 4 Boulevard Henri IV,

F-34060 Montpellier Cedex 1, France

${ }^{*}$ Corresponding author

e-mail: pharmaco@sc.univ-montp1.fr, Fax: +33-4-67601182

"Published by error as Sophie

Keywords: Peripheral benzodiazepine receptors, Insulin secretion, PK 11195, Rat isolated pancreas 


\begin{abstract}
We have recently shown that benzodiazepines with high affinity for peripheral-type receptors such as 4'-chlordiazepam inhibit insulin secretion in vitro. PK 11195 [1-(2-chlorophenyl)-Nmethyl-N-(1-methylpropyl)-3-isoquinoline-carboxamide], a potent and selective ligand for peripheral benzodiazepine binding sites, was also shown to inhibit insulin release from rat pancreatic islets. Both substances have been reported to interact with mitochondrial binding sites. Hence, the present study was performed to investigate the effects of PK 11195 on insulin secretion induced by either a metabolic or a non-metabolic stimulus. In the rat isolated pancreas perfused at a constant pressure with a Krebs-bicarbonate buffer containing a slightly stimulating glucose concentration $(8.3 \mathrm{mM})$, PK $11195\left(10^{-7}-10^{-5} \mathrm{M}\right)$ induced a progressive and concentration-dependent decrease in insulin secretion. Simultaneously, we recorded the effects on the pancreatic flow rate; in contrast to 4'-chlordiazepam, previously shown to induce vasodilation in the same preparation, PK11195 was ineffective. The differential effects of these two substances on vascular resistance and insulin secretion may suggest the existence of different subtypes of peripheral benzodiazepine receptors on pancreatic $\beta$-cells and vessels. A metabolic stimulation of insulin secretion was induced by a glucose increment from $4.2 \mathrm{mM}$ to $8.4 \mathrm{mM}$ or by $2 \mathrm{mM} \alpha$-ketoisocaproic acid (KIC), which is directly metabolized in the mitochondria; these stimulations could be reduced by $10^{-5}$ M PK $11195(\mathrm{P}<0.05)$. In contrast, the drug was ineffective on the insulin secretion induced by $5 \mathrm{mM}$ or $10 \mathrm{mM} \mathrm{KCl}$ in the presence of a nonstimulating glucose concentration $(4.2 \mathrm{mM})$. These results suggest that PK 11195 inhibits insulin secretion by interfering with mitochondrial oxidative metabolism.
\end{abstract}




\section{Introduction}

In addition to interacting with central-type benzodiazepine receptors that mediate anxiolytic, anticonvulsant and sedative effects, benzodiazepines bind to peripheraltype receptors that are distributed both in the brain and in a variety of peripheral tissues (Anholt et al. 1985; Verma and Snyder 1989). The physiological role of the peripheral benzodiazepine receptors (PBRs) is not yet clearly elucidated (Verma and Snyder 1989). These receptors, often associated with mitochondrial membranes (Anholt et al. 1986; Snyder et al. 1990), have been identified in glandular tissues including the pancreas (De Souza et al. 1985). More recently, a biochemical characterization of PBRs has been performed in porcine pancreatic islets (Cosimi et al. 1994; Marchetti et al. 1996) and in isolated human pancreatic islets (Giusti et al. 1997).

Experiments in vitro have shown that 4'-chlordiazepam, which displays high affinity for peripheral receptors (Schoemaker et al. 1983), inhibited in a concentration-dependent manner the glucose-induced insulin secretion whereas clonazepam, which binds very weakly to peripheral sites (Braestrup and Squires 1977), was ineffective (Petit et al. 1992). The signaling mechanism of the inhibiting effect of 4'-chlordiazepam was shown to be independent of the adenylyl cyclase-cAMP pathway (Petit et al. 1993). In vivo, diazepam was reported to impair glucose tolerance in the rat (Seyer-Hansen 1972). More recently, Najim et al. (1989) reported that 4'-chlordiazepam increased glycaemia after intraperitoneal administration in mice.

On the other hand, a trend to increased glycaemia without significant modification of insulinemia was shown after a single dose administration of diazepam in healthy volunteers (Syvälahti and Kanto 1975). An aggravation of hyperglycaemia has been reported during benzodiazepine treatment in diabetic patients (Zumoff and Hellman 1977).

A pilot investigation in patients treated with the imidazopyridine compound alpidem, which displays high affinity for PBRs, was reported to alter glucose tolerance (Bottaï et al. 1995).

These experimental and clinical results suggest that PBR ligands may interfere with the control of insulin secretion and the glucose homeostasis. The progressive inhibitory effect of the PBR agonists (Petit et al. 1992) together with the mitochondrial localization of these receptors suggest that they may act intracellularly.

The aim of the present study was to further investigate the mechanism whereby PBR agonists decrease glucoseinduced insulin secretion, using a potent ligand of these receptors: 1- 
(2-chlorophenyl)-N -methyl-N -(1-methylpropyl)- 3-isoquinoline-carboxamide (PK 11195). This non-benzodiazepine compound was initially proposed as a putative antagonist (Le Fur et al. 1983a, 1983b). However, in rat isolated islets, it did not counteract the inhibitory effect of 4'-chlordiazepam on insulin secretion but elicited by itself a potent inhibitory response (Petit et al. 1992). In the present work, the action of PK 11195 was studied on isolated and perfused rat pancreas with monitoring of insulin and vascular responses. We investigated comparatively the effects of PK 11195 on either a metabolic [glucose increment or a -ketoisocaproic acid (a $\mathrm{KIC}$ ) infusion] or a nonmetabolic ( $\mathrm{KCl}$ infusion) stimulus of the insulin-secreting $\beta$-cell.

\section{Materials and methods}

\section{Isolated perfused pancreas}

Experiments were performed on male Wistar rats weighing 320-370 g and fed ad libitum. The pancreas was completely isolated from neighboring tissues according to a technique previously described (Loubatières et al. 1969) and perfused through its own arterial system with a Krebs-Ringer bicarbonate buffer containing $8.3 \mathrm{mM}$ or $4.2 \mathrm{mM}$ glucose and 2 $\mathrm{g} / \mathrm{l}$ bovine serum albumin. A mixture of $\mathrm{O}_{2}(95 \%)$ and $\mathrm{CO}_{2}(5 \%)$ was bubbled through this medium at atmospheric pressure. The $\mathrm{pH}$ of the solution was 7.4. The preparation was maintained at $37.5^{\circ} \mathrm{C}$. Each organ was perfused at a constant pressure $\left(40-50 \mathrm{cmH}_{2} \mathrm{O}\right)$ selected so as to produce a flow rate of $2.5 \mathrm{ml} / \mathrm{min}$ at the start of the experiment; under these conditions, any change in the flow rate reflects a change in vascular resistance.

\section{Experimental protocol}

In all experiments a 30-min adaptation period was allowed before the first sample was taken for insulin assay. Two sets of experiments were performed. In a first set, the pancreas was continuously perfused with the physiological solution containing a slightly stimulating glucose concentration $(8.3 \mathrm{mM})$ and from time $45 \mathrm{~min}$, PK 11195 was infused for $30 \mathrm{~min}$ at different concentrations: $10^{-7}-3 \times 10^{-5} \mathrm{M}$. In the second set of experiments, the pancreas was perfused from the beginning by a physiological medium containing a non-stimulating glucose concentration (4.2 mM). PK 11195 was added for $60 \mathrm{~min}$ from time $30 \mathrm{~min}$; the stimulating agent of insulin secretion was added for $30 \mathrm{~min}$ or $20 \mathrm{~min}$ from time $60 \mathrm{~min}$. Each effluent fraction was collected for $1 \mathrm{~min}$ in a graduated tube; the flow rate was measured and a fraction of the sample was immediately frozen for insulin immunoassay. 


\section{Insulin assay}

Insulin was assayed by the radioimmunological method of Herbert et al. (1965) using $\left[{ }^{125} \mathrm{I}\right]$ insulin (C.I.S. International, Gif-Sur-Yvette, France), purified rat insulin as standard (Novo, Copenhagen, Denmark), the biological activity of which was $14.2 \mu \mathrm{U} / \mathrm{ng}$, and antiinsulin serum (ICN Biochemicals, Miles, Puteaux, France). The sensitivity of the assay was 0.1 $\mathrm{ng} / \mathrm{ml}$. Insulin output from perfused pancreas is expressed as $\mathrm{ng} / \mathrm{min}$ and was determined by multiplying the hormone concentration in the effluent fraction by the flow rate.

\section{Expression of results and statistical analysis}

For the kinetics of insulin output, the results are expressed as changes in relation to the value at time 45 min taken as $100 \%$ (experiments with $8.3 \mathrm{mM}$ glucose), or in absolute values (ng/min) in the experiments with $4.2 \mathrm{mM}$ glucose. The mean insulin output rate was calculated as follows: the area under the curve for the PK 11195 infusion period divided by the number of minutes (AUC/30). The data are expressed as means \pm standard error of the mean (SEM). They were submitted to Student's $t$-test or to analysis of variance and Newman- Keuls multiple comparison test (Zar 1974).

\section{Medium and chemicals}

The medium used was a Krebs-bicarbonate buffer (composition in $\mathrm{mM}: \mathrm{NaCl} 118, \mathrm{KCl}$ 4.7, $\mathrm{MgSO}_{4} 1.2, \mathrm{KH}_{2} \mathrm{PO}_{4} 1.2, \mathrm{NaHCO}_{3} 25, \mathrm{CaCl}_{2} 2.5$ ) equilibrated with $95 \% \mathrm{O}_{2}-5 \% \mathrm{CO}_{2}, \mathrm{pH}$ 7.4. PK 11195 was dissolved in dimethylsulfoxide (DMSO), and the appropriate concentration of drugs was added to the solution so that the final concentration of DMSO never exceeded $0.1 \%$. Although DMSO was ineffective alone at the concentration used, it was added to the control media. PK 11195, bovine serum albumin (Fraction V) and $\alpha$-ketoisocaproic acid were from Sigma Chemical (St. Louis, Mo., USA); DMSO was from Merck (Darmstadt, Germany).

\section{Results}

Effects of PK 11195 on insulin secretion and vascular flow rate from the rat isolated pancreas perfused with a slightly stimulating glucose concentration

In the presence of $8.3 \mathrm{mM}$ glucose, PK $11195\left(10^{-6} \mathrm{M}\right.$ and $\left.10^{-5} \mathrm{M}\right)$ induced a progressive and sustained inhibition of insulin secretion (Fig. 1). This inhibition is statistically significant from time $65 \mathrm{~min}$ with the lower concentration, and from time $49 \mathrm{~min}$ with the higher 
concentration. In pancreas perfused with DMSO alone (controls) the rate of insulin secretion is not significantly modified throughout experiments and averaged $15.6 \pm 1.9 \mathrm{ng} / \mathrm{min}$ at time 45 min (reference value). The mean insulin output rate during the 30 min of PK 11195 infusion (AUC/30) is significantly decreased to $79.1 \pm 2.7 \%(\mathrm{P}<0.01)$ and $65.9 \pm 6.7 \%(\mathrm{P}<0.01)$ for $10^{-6}$ $\mathrm{M}$ and $10^{-5} \mathrm{M}$ PK 11195 , respectively, as compared with $98.0 \pm 6.0 \%$ for control experiments. After stopping PK 11195 infusion, the insulin output progressively returned to control values. Furthermore, the effect of PK 11195 was concentration-dependent in the range of $10^{-7}-10^{-5} \mathrm{M}$, the maximal effect being obtained at this latter concentration (Fig. 2).

In addition, the infusion of PK 11195 at the concentrations of $10^{-6} \mathrm{M}$ and $10^{-5} \mathrm{M}$, which are effective in reducing insulin secretion, does not alter the pancreatic vascular flow rate recorded in the same experiments (Table 1).

Effects of PK 11195 on insulin secretion inducedby a metabolic stimulation of insulin secretion

\section{Glucose increment}

The increase in glucose from a non-stimulating concentration $(4.2 \mathrm{mM})$ to a slightly stimulating concentration $(8.4 \mathrm{mM})$ induces a biphasic insulin secretion (Fig. 3). The infusion of PK $11195\left(10^{-5} \mathrm{M}\right)$ does not modify the insulin secretion in the presence of $4.2 \mathrm{mM}$ glucose, but it significantly decreases the biphasic insulin response to the glucose increment: it reduces the peak of the first phase as well as the amplitude of the second phase (Fig. 3). The mean of areas under the curves (AUC) in the presence of PK 11195 is significantly different from the control AUC during the first and second phases. The insulin output during the first $5 \mathrm{~min}$ (first phase) and the following $25 \mathrm{~min}$ (second phase) of $4.2 \mathrm{mM}$ glucose addition was $13.6 \pm 2.1 \mathrm{ng}$ and $83.7 \pm 14.3 \mathrm{ng}$ for control experiments, respectively; the values fall to $9.0 \pm 1.4 \mathrm{ng}(\mathrm{P}<0.04)$ and 57.6 $\pm 6.4 \mathrm{ng}(\mathrm{P}<0.05)$, respectively, for the treated pancreas.

\section{$\underline{\alpha-k e t o i s o c a p r o i c ~ a c i d ~(K I C) ~ i n f u s i o n ~}$}

In the presence of glucose $4.2 \mathrm{mM}, \alpha$-KIC $2 \mathrm{mM}$ induces a biphasic insulin secretion (Fig. 4). After a peak which culminates at the second min and lasts $5 \mathrm{~min}$, a second phase of insulin secretion increase is observed throughout the $\alpha$-KIC infusion. A PK $11195\left(10^{-5} \mathrm{M}\right)$ infusion $30 \mathrm{~min}$ before the $\alpha$-KIC infusion partially inhibits the biphasic insulin response (Fig. 4). The means of AUC in the presence of PK 11195 are significantly different from those of 
control AUC during the first and the second phase. The insulin output during the first $5 \mathrm{~min}$ (first phase) and the following $25 \mathrm{~min}$ (second phase) of $\alpha$-KIC infusion are, for control experiments, $23.9 \pm 3.5 \mathrm{ng}$ and $100.1 \pm 12.6 \mathrm{ng}$, respectively; for the PK 11195-treated pancreas, they are only $15.5 \pm 2.7 \mathrm{ng}(\mathrm{P}<0.04)$ and $64.7 \pm 10.7 \mathrm{ng}(\mathrm{P}<0.02)$, respectively.

Effects of PK 11195 on insulin secretion induced by a non-metabolic stimulation of insulin secretion: $\mathrm{KCl}$ infusion

In the presence of a non-stimulating glucose concentration $(4.2 \mathrm{mM}) \mathrm{KCl} 10 \mathrm{mM}$ induces a monophasic insulin response (Fig. 5). The peak of insulin secretion reaches its highest point at the second min of $\mathrm{KCl}$ infusion. The prior administration of PK $11195\left(10^{-5} \mathrm{M}\right) 30 \mathrm{~min}$ before $\mathrm{KCl}$ infusion does not significantly modify the effect of this latter substance (Fig. 5): the mean AUC/10 from min 60 to min 70 was $2.2 \pm 0.5 \mathrm{ng} / \mathrm{min}$ in the presence of PK11195 vs. $2.7 \pm 0.4 \mathrm{ng} / \mathrm{min}$ for controls. Furthermore, the effect of a lower concentration of $\mathrm{KCl}(5 \mathrm{mM})$ is still unaffected by PK 11195, although its magnitude is lower: the mean AUC/10 from min 60 to $\min 70$ was $0.9 \pm 0.2 \mathrm{ng} / \mathrm{min}$ in the presence of PK $11195 \mathrm{vs} .1 .1 \pm 0.4 \mathrm{ng} / \mathrm{min}$ for controls.

\section{Discussion}

The present results clearly show that PK 11195, a selective isoquinoline-carboxamide ligand of PBRs, inhibits insulin secretion induced by glucose in vitro in the rat isolated pancreas. This effect is concentration-dependent and of progressive setting-up, which is in accordance with an intracellular site of action. A similar decrease in insulin secretion was previously reported with the benzodiazepine PBRs agonist 4'-chlordiazepam on the same preparation (Petit et al. 1992). However, when comparing the effective concentrations of the two drugs it can be noted that the inhibitory effect of PK 11195 is about tenfold more potent than that of 4'-chlordiazepam. On the other hand, PK 11195 was completely ineffective on the vascular flow rate of the rat isolated pancreas. In contrast, in the same experimental conditions, 4'-chlordiazepam was previously shown to induce a vasodilator response of the pancreatic vascular bed (Petit et al. 1992). The differential effects on vascular resistance of these two compounds, which both inhibit insulin secretion, suggest that two different subtypes of PBRs may be recognized in pancreatic $\beta$-cells and in pancreatic vascular cells. The reduction of glucose-induced insulin secretion by PBR ligands could explain the increase in blood glucose 
concentration, which was reported in mice in vivo after an intraperitoneal administration of 4'chlordiazepam (Ro 5-4864) by Najim et al. (1989). In that study, when PK11195 was administered before 4'-chlordiazepam no antagonism was observed, but a greater increase in blood glucose, which is in agreement with our results. Thus, PK11195 as well as 4'chlordiazepam are able to impair glucose homeostasis and insulin secretion, and we further investigated at which level in the $\beta$-cell a PBR ligand could modify the insulin secretion. It is worth recalling that glucose stimulates insulin secretion by being metabolized first with glycolysis and then in the mitochondrial citric acid cycle. The oxidative events lead to an increased cytoplasmic ATP/ADP ratio, which inhibits the ATP-sensitive $\mathrm{K}^{+}$channel $\left(\mathrm{K}_{\mathrm{ATP}}\right.$ channels). This results in a membrane depolarization and the opening of voltage-dependent $\mathrm{Ca}^{2+}$ channels, leading to increased cytoplasmic calcium concentration and the initiation of exocytosis of the insulin-containing secretory granules (Rorsman 1997). Since the stimulussecretion coupling of glucose in the $\beta$-cell involves both metabolic and electrophysiological events, we compared the effects of PK 11195 on insulin secretion induced by metabolic stimulus or membrane depolarization. The stimulation of insulin secretion by potassium depolarization ( $\mathrm{KCl}$ infusion) was not modified by PK11195. Thus, it may be suggested that this drug does not directly interfere with the membrane potential or the subsequent electrophysiological events such as the opening of voltage- dependent calcium channels. Moreover, the progressive time course of the effect of PK 11195 on glucose-induced insulin secretion contrasts with the immediate effect of a potassium channel opener such as diazoxide in similar conditions (Mariani et al. 1971). Hence, it may also be suggested that PK 11195 does not directly block the $\mathrm{K}_{\mathrm{ATP}}$ channels; it may rather act upstream of that target. The metabolism of glucose involves both glycolysis and oxidative events in the mitochondrial citric acid cycle. In contrast, the deamination product of the amino acid L -leucine, $\alpha$-ketoisocaproate (KIC), is a fuel secretagogue which is directly metabolized in the mitochondria (Panten et al. 1974). A low millimolar concentration of KIC was chosen because it has been reported to be insulinotropic in rodents (Ashcroft 1981); furthermore, higher concentrations have been shown to directly inhibit the $\mathrm{K}_{\mathrm{ATP}}$ channel activity (Bränström et al. 1998) and the low concentration used is insufficient to directly reduce channel activity to a significant extent. Thus, an effect on KIC-induced insulin release may discriminate between actions on the glycolytic vs. the mitochondrial part of glucose signaling. Under our experimental conditions, a glucose increment from $4.2 \mathrm{mM}$ to $8.4 \mathrm{mM}$ or addition of $2 \mathrm{mM}$ KIC to $4.2 \mathrm{mM}$ glucose induced a biphasic stimulation of insulin secretion of similar magnitude. These effects were both reduced 
by the PBR agonist PK 11195, suggesting that this drug may interfere with the oxidative events implicated in glucose-induced insulin release. This functional result is in agreement with the mitochondrial localization of PBRs. To summarize, the insulin-inhibitory effect of PK 11195 seems to proceed independently of events related to membrane depolarization. In contrast, it seems to be dependent on intracellular metabolism, particularly mitochondrial oxidative events. Therefore, it may be suggested that PBR agonists act via mitochondrial benzodiazepine receptors in the pancreatic $\beta$-cell, and decrease insulin release by reducing oxidative metabolism. Furthermore, our results suggest the existence of different subtypes of peripheral benzodiazepine receptors on pancreatic $\beta$-cells and vessels.

\section{Acknowledgements}

The authors thank V. Montesinos and N. Linck for technical assistance. 


\section{References}

Anholt RRH, De Souza EB, Oster-Granite ML, Snyder SH (1985) Peripheral-type benzodiazepines receptors: autoradiographic localization in whole-body sections of neonatal rats. J Pharmacol Exp Ther 233:517-526

Anholt RRH, Pedersen PL, De Souza EB, Snyder SH (1986) The peripheral-type benzodiazepine receptor: localization to the mitochondrial outer membrane. J Biol Chem 261:576-583

Ashcroft SJH (1981) Metabolic controls of insulin secretion. In: Cooperstein SJ, Watkins D (eds) The Islets of Langerhans. Biochemistry, physiology and pathology. Academic Press, New York, pp 117-148

Bottaï T, Cartault F, Pouget R, Blayac JP, Petit P (1995) An imidazopyridine anxiolytic alters glucose tolerance in patients: a pilot investigation. Clin Neuropharmacol 18:1-4

Braestrup C, Squires R (1977) Specific benzodiazepine receptors in rat brain characterized by high-affinity [3H]diazepam binding. Proc Natl Acad Sci USA 74:3805-3809

Bränström R, Efendic S, Berggren PO, Larsson O (1998) Direct inhibition of the pancreatic bcell ATP-regulated potassium channel by a-ketoisocaproate. J Biol Chem 273:1411314118

Cosimi S, Giusti L, Marchetti P, Trincavelli L, Giannarelli R, Martini C, Arvia C, Lucacchini A, Navalesi R (1994) Benzodiazepine receptors in porcine pancreatic islets. Diabetologia 37 [Suppl 1]:A111

De Souza EB, Anholt RRH, Murphy KMM, Snyder SH, Kuhar MJ (1985) Peripheral-type benzodiazepine receptors in endocrine organs: autoradiographic localization in rat pituitary, adrenal, and testis. Endocrinology 116:567-573

Giusti L, Marchetti P, Trincavelli L, Lupi R, Martini C, Lucacchini A, Del Guerra S, Tellini C, Carmellini M, Navalesi R (1997) Peripheral benzodiazepine receptors in isolated human pancreatic islets. J Cell Biochem 64:273-277

Herbert V, Law KS, Gotlieb CW, Bleicher SJ (1965) Coated charcoal immunoassay of insulin. J Clin Endocrinol Metab 25: 1375-1384 50

Le Fur G, Guilloux F, Rufat P, Bénavidès J, Uzan A, Renault C, Dubroeucq MC, Guérémy C (1983a) Peripheral benzodiazepine binding sites: effects of PK 11195 1-(2 chlorophenyl)Nmethyl-( 1-methylpropyl)-3 isoquinolinecarboxamide. Life Sci 32:1849-1856

Le Fur G, Vaucher N, Perrier ML, Flamier A, Bénavidès J, Renault C, Dubroeucq MC, Guérémy C, Uzan A (1983b) Differentiation between two ligands for peripheral benzodiazepine binding sites, [3H]Ro 5-4864 and [3H]PK 11195, by thermodynamic studies. Life Sci 33:449-457

Loubatières AL, Mariani MM, De Malbosc H, Ribes G, Chapal J (1969) Etude expérimentale d'un nouveau sulfamide hypoglycémiant particulièrement actif, le HB 419 ou glibenclamide. I. Action bêtacytrope et insulinosécrétrice. Diabetologia 5:1-10

Marchetti P, Trincavelli L, Giannarelli R, Giusti L, Coppelli A, Martini C, Navalesi R, Lucacchini A (1996) Characterization of peripheral benzodiazepine receptors in purified large mammal pancreatic islets. Biochem Pharmacol 51:1437-1442 
Mariani MM, Loubatières A, Chapal J (1971) Etude de l'action inhibitrice du diazoxide sur l'insulino-sécrétion du pancreas isolé et perfusé du rat: absence d'implication des récepteurs a-adrénergique. CR Soc Biol 169:1398-1401

Najim RA, Al-Essa LY, Al-Jibouri LM (1989) Effect of some drugs acting at the peripheraltype benzodiazepine receptors on blood glucose in mice. Med Sci Res 17:783-784

Panten U, Christians J, Kriegstein EW, Poser W, Hasselblatt A (1974) Studies on the mechanism of D-leucine and a-ketoisocaproic acid-induced insulin release from perifused isolated pancreatic islets. Diabetologia 10:149-154

Petit P, Manteghetti M, Berdeu D, Ribes G, Loubatières-Mariani MM (1992) Effects of a peripheral-type benzodiazepine on glucose- induced insulin secretion. Eur J Pharmacol 221:359-363

Petit P, Chapal J, Manteghetti M, Loubatières-Mariani MM (1993) Recherche du mécanisme de l'inhibition de la sécrétion d'insuline induite par une benzodiazépine périphérique, le 4'-chlordiazépam. CR Soc Biol 187:536-541

Rorsman P (1997) The pancreatic beta-cell as a fuel sensor: an electrophysiologist's viewpoint. Diabetologia 40:487-495

Schoemaker H, Boles RG, Horst WD, Yamamura HI (1983) Specific high-affinity binding sites for [3H]Ro-5-4864 in rat brain and kidney. J Pharmacol Exp Ther 225:61-69

Seyer-Hansen K (1972) The effects of diazepam on glucose tolerance in rats. Diabetologia 8:66-67

Snyder SH, McEnery MW, Verma A (1990) Molecular mechanisms of peripheral benzodiazepine receptors. Neurochem Res 15:119-123

Syvälahti EGK, Kanto JH (1975) Serum growth hormone, serum immunoreactive insulin and blood glucose response to oral and intravenous diazepam in man. Int J Clin Pharmacol $12: 74-82$

Verma A, Snyder SH (1989) Peripheral type benzodiazepine receptors. Annu Rev Pharmacol Toxicol 29:307-322 Zar JH (1974) Multiple comparisons. In: Zar JH (ed) Biostatistical analysis. Prentice Hall, Englewood Cliffs, pp 151-162

Zumoff B, Hellman L (1977) Aggravation of diabetic hyperglycemia by chlordiazepoxide. JAMA 237:1960-1961 


\begin{tabular}{|c|c|c|c|c|c|c|c|c|c|}
\hline & \multicolumn{9}{|l|}{ Minutes } \\
\hline & 45 & 46 & 47 & 48 & 49 & 50 & 55 & 60 & 75 \\
\hline Control & $2.43 \pm 0.06$ & $2.46 \pm 0.06$ & $2.43 \pm 0.07$ & $2.49 \pm 0.05$ & $2.49 \pm 0.06$ & $2.49 \pm 0.05$ & $2.46 \pm 0.06$ & $2.47 \pm 0.05$ & $2.54 \pm 0.07$ \\
\hline PK $1119510^{-6} \mathrm{M}$ & $2.49 \pm 0.03$ & $2.46 \pm 0.05$ & $2.46 \pm 0.07$ & $2.49 \pm 0.07$ & $2.49 \pm 0.08$ & $2.49 \pm 0.08$ & $2.49 \pm 0.07$ & $2.54 \pm 0.07$ & $2.51 \pm 0.07$ \\
\hline PK $1119510^{-5} \mathrm{M}$ & $2.48 \pm 0.03$ & $2.49 \pm 0.03$ & $2.49 \pm 0.03$ & $2.51 \pm 0.04$ & $2.53 \pm 0.05$ & $2.52 \pm 0.06$ & $2.51 \pm 0.07$ & $2.49 \pm 0.09$ & $2.49 \pm 0.10$ \\
\hline
\end{tabular}

\section{Table 1}

Effects of PK 11195 on vascular flow rate from the rat isolated pancreas perfused in the presence of $8.3 \mathrm{mM}$ glucose. The results (mean of six experiments) are expressed as $\mathrm{ml} / \mathrm{min} \pm \mathrm{SEM}$ 


\section{Figure legends}

\section{Figure 1}

Effects of PK $11195\left(\boldsymbol{\Delta} 10^{-6} \mathrm{M}, 1^{-5} \mathrm{M}\right)$ on insulin secretion from the rat isolated pancreas perfused in the presence of $8.3 \mathrm{mM}$ glucose. Results from 6 individual experiments are expressed as percentages of the value at time $45 \mathrm{~min}$ taken as reference. At this time, insulin release averaged $18.6 \pm 5.8 \mathrm{ng} / \mathrm{min}$ and $23.1 \pm 6.2 \mathrm{ng} / \mathrm{min}$ for PK 11195 -treated pancreas, $10^{-6} \mathrm{M}$ and $10^{-5} \mathrm{M}$, respectively; it was $15.6 \pm 1.9 \mathrm{ng} / \mathrm{min}$ for DMSO control experiments $(\mathrm{O})$. $* * \mathrm{P}<0.01$.

\section{Figure 2}

Concentration-response curve for the inhibitory effect of PK 11195 on glucose-induced insulin secretion. Each point is the result of 6-7 individual experiments and represents the mean $( \pm \mathrm{SEM})$ reduction in the insulin output rate (AUC/30 as a percentage) in comparison with control values.

\section{Figure 3}

Effects of PK 11195 on the insulin secretion induced by an increment of glucose concentration from $4.2 \mathrm{mM}$ to $8.4 \mathrm{mM}$ ( $\bigcirc$ controls, $\bigcirc \mathrm{PK} 1119510^{-5} \mathrm{M}$ ). Results are expressed as means \pm SEM of 10 experiments.

\section{Figure 4}

Effects of PK $1119510^{-5} \mathrm{M}(\mathbf{O})$ on the insulin secretion induced by an infusion of KIC $2 \mathrm{mM}$; ( $\bigcirc$ controls). Results are expressed as means \pm SEM. of 11 experiments.

\section{Figure 5}

Effects of PK $1119510^{-5} \mathrm{M}(\mathbf{O})$ on the insulin secretion induced by an infusion of $\mathrm{KCl} 10 \mathrm{mM}$; (O) controls). Results are expressed as means \pm SEM of 7 experiments. 
Glucose $8.3 \mathrm{mM}$

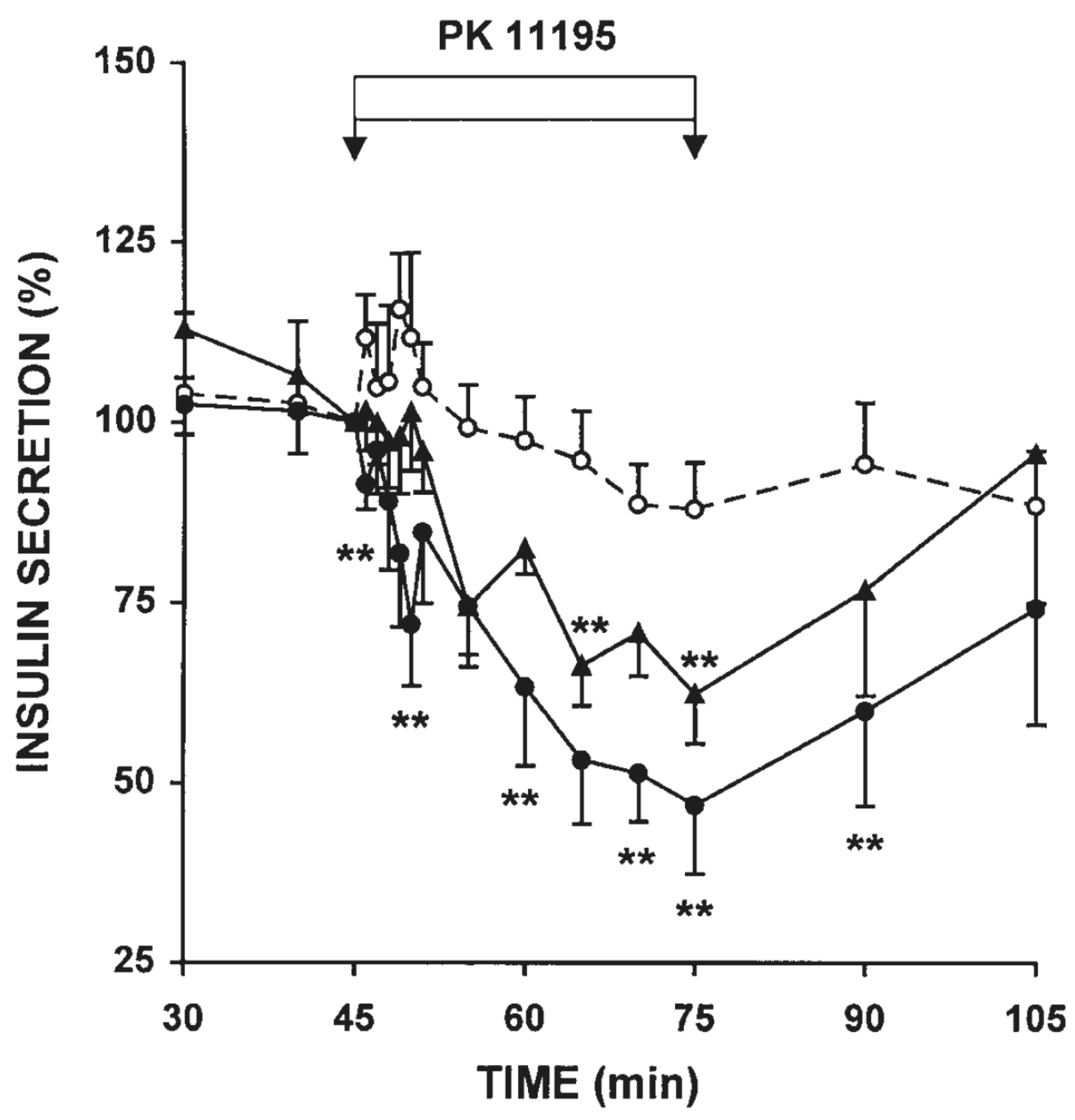

Figure 1 


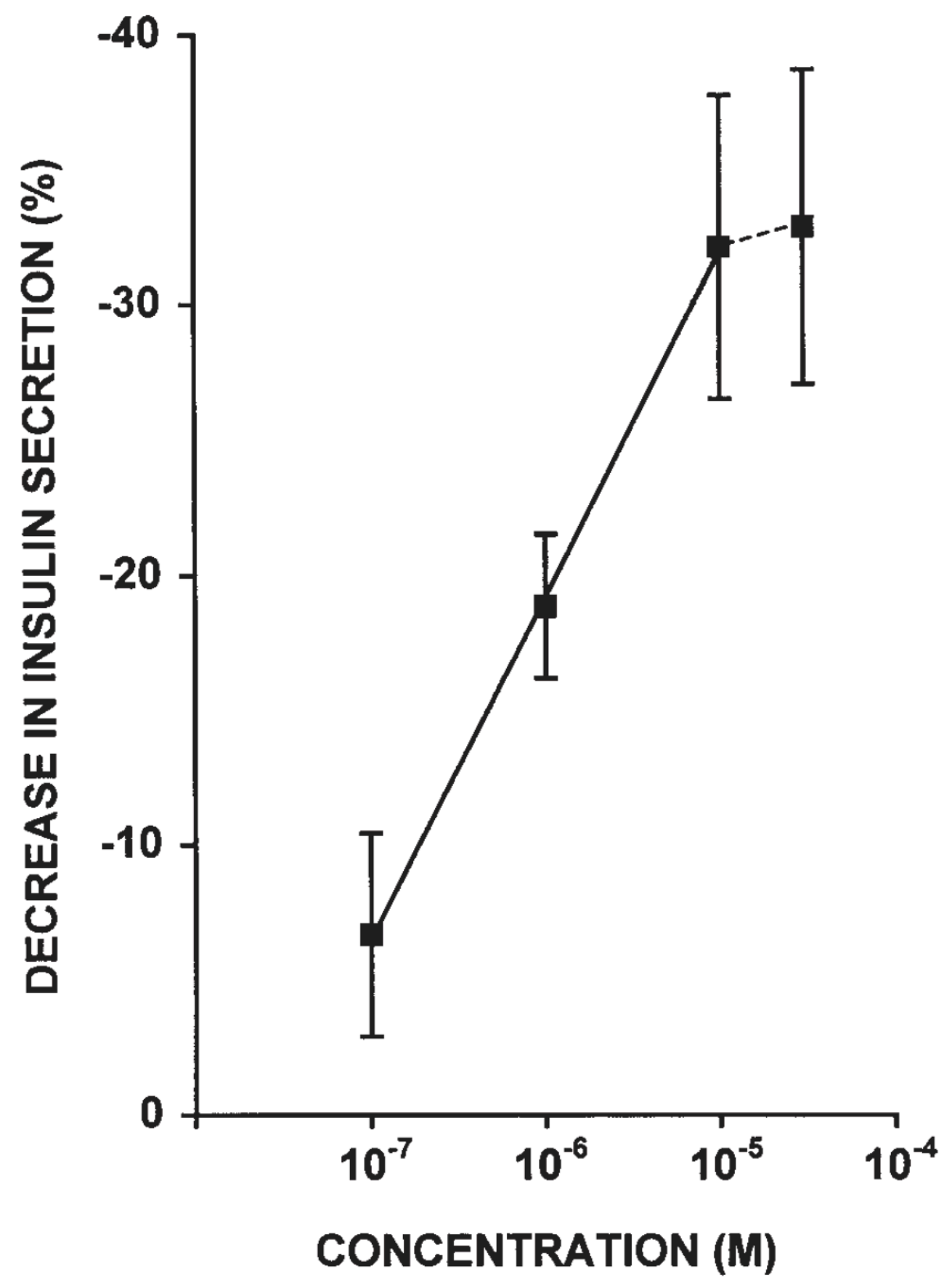

Figure 2 


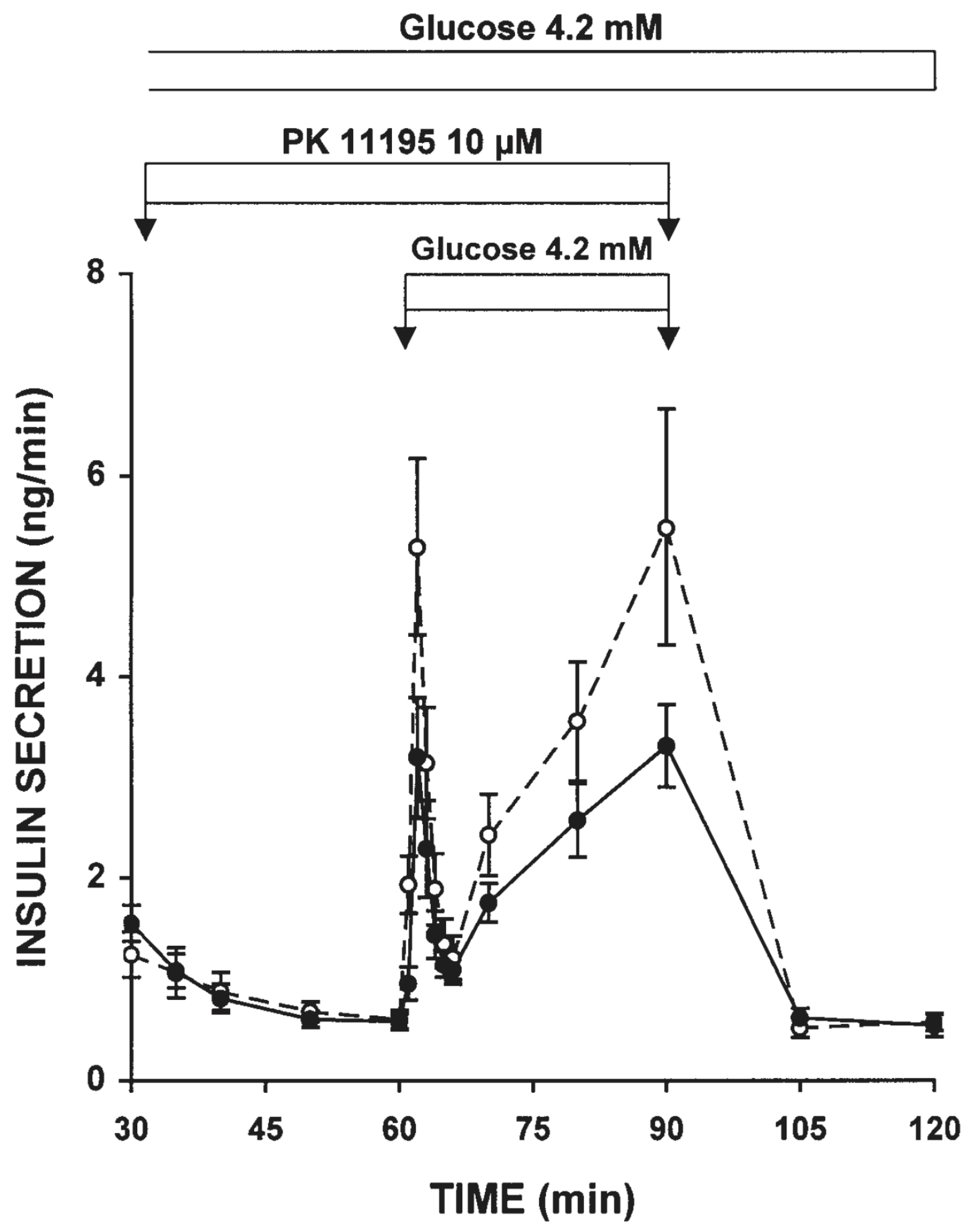

Figure 3 
Glucose $4.2 \mathrm{mM}$

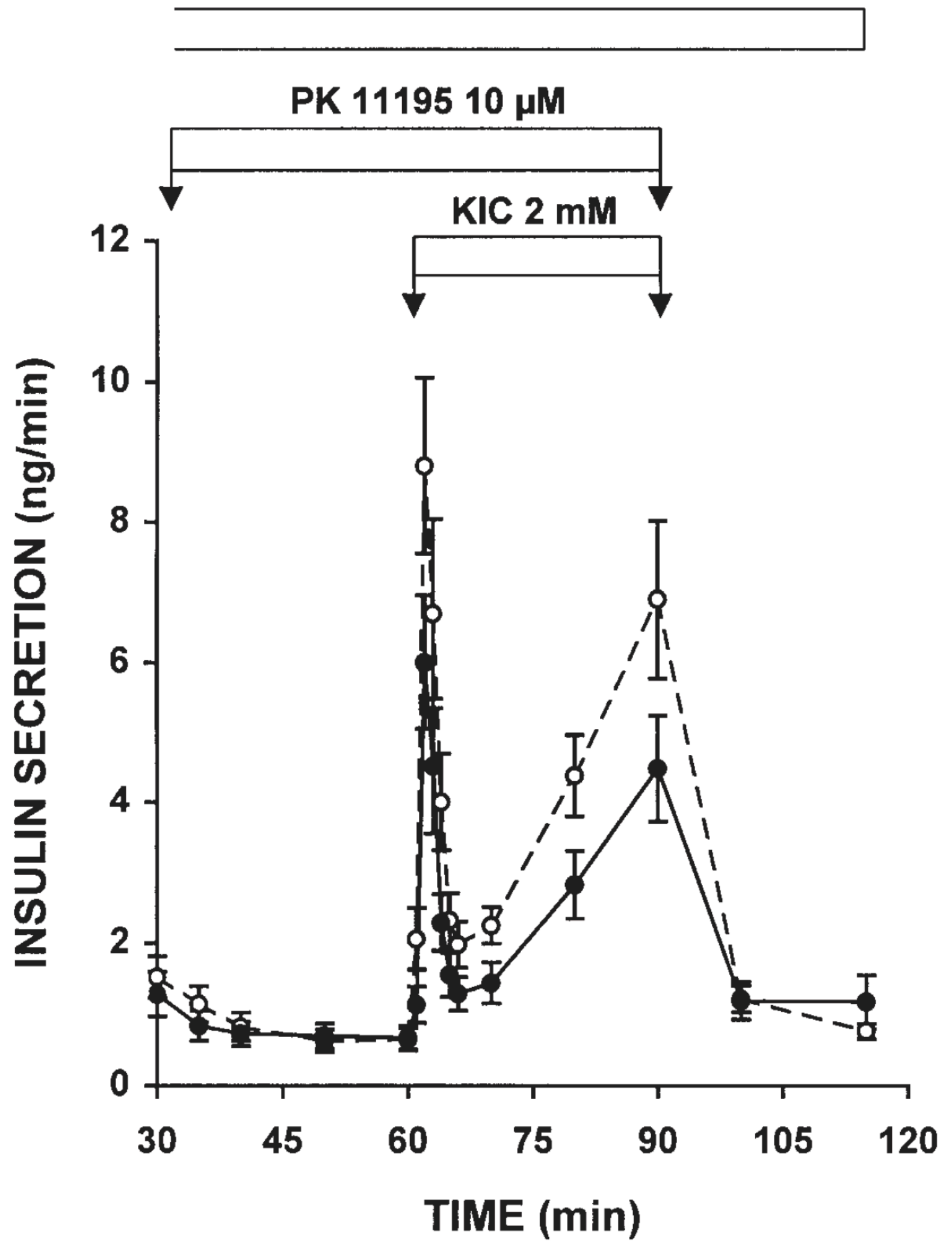

Figure 4 


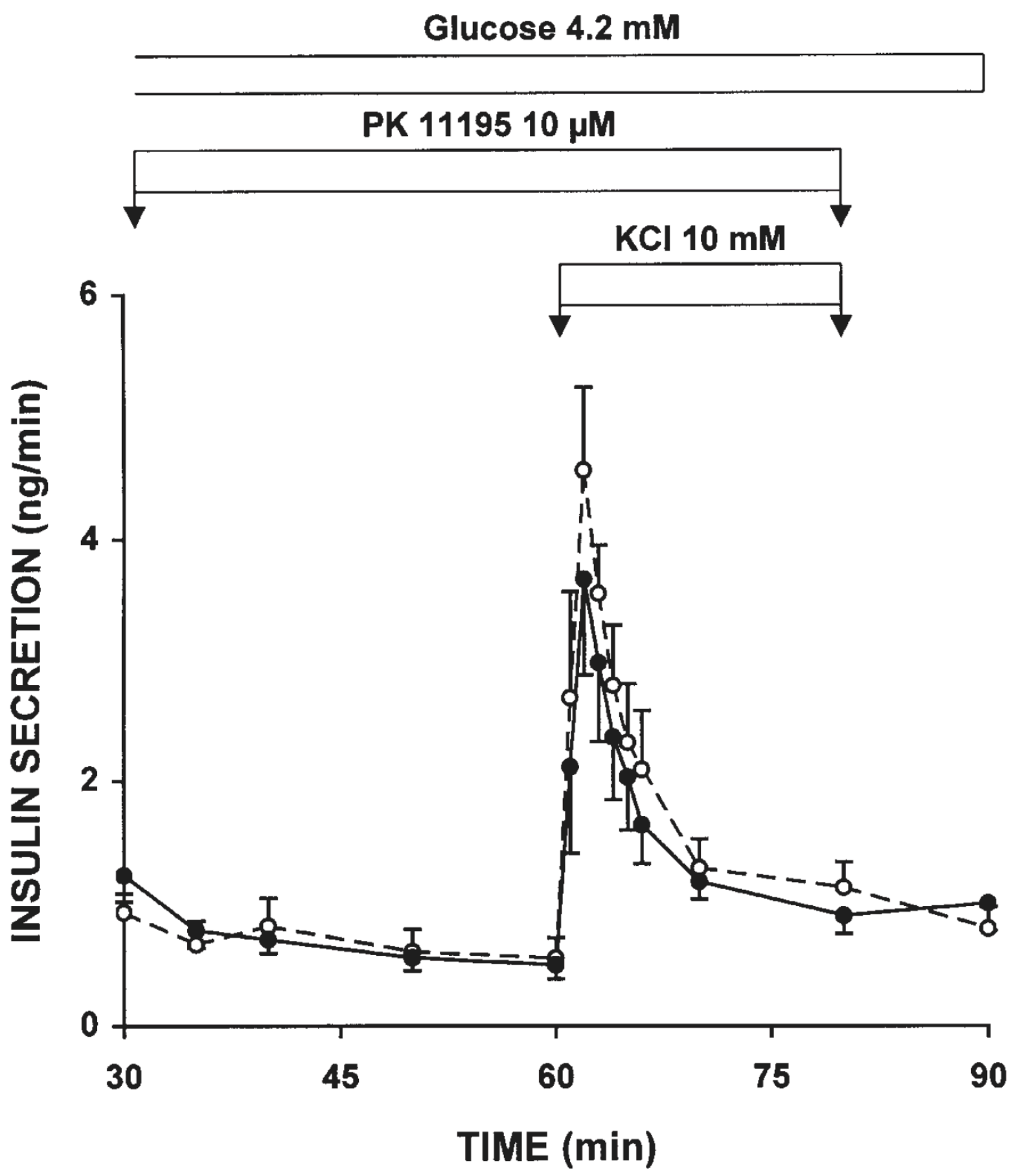

Figure 5 